\title{
Triple-Negative Breast Cancer: Clinical and Histological Correlations
}

\author{
Zeinab Elsawaf Hans-Peter Sinn \\ Department of Pathology, University of Heidelberg, Germany
}

\section{Keywords}

Breast cancer, molecular subtypes

\section{Summary}

Triple-negative breast cancer (TNBC) is characterized by the lack of estrogen and progesterone receptors and the lack of HER2 expression or amplification. Much interest has recently been focused on these triple-negative (TN) subtypes because they may be aggressive and are more likely to recur and metastasize than other subtypes of breast cancer. TNBC accounts for approximately 10-24\% of all breast cancer cases, and typically it occurs in younger patients and in patients with BRCA1 mutation. There is a substantial heterogeneity of TNBCs both at the morphological and the molecular level, but there are also common features, such as low tumor grade and accelerated tumor proliferation. Morphologically, TNBC may present as invasive ductal, metaplastic, medullary, apocrine, or other types. Molecularly, they are most frequently associated with a basal phenotype, but there is a distinct subgroup of cancers that are not of basal type and belong to the claudin-low or molecular-apocrine type. The basal phenotype is frequently associated with the loss of BRCA1.

\section{Introduction}

Breast cancer is a highly heterogeneous disease at both the molecular and the clinical level. The histopathologic World Health Organization (WHO) classification of breast cancer [1] stratifies tumors based on their morphological tumor characteristics, with little reference to non-morphological (immunohistochemical or molecular) features. This builds upon the

\author{
Schlüsselwörter \\ Mammakarzinom, molekulare Subtypen
}

\section{Zusammenfassung}

Das tripel-negative Mammakarzinom (TNBC) ist charakterisiert durch die fehlende Expression von Östrogenund Progesteronrezeptoren sowie durch die fehlende Überexpression bzw. Amplifikation von HER2. Aufgrund der generell höheren Aggressivität und Rezidivhäufigkeit im Vergleich mit anderen Phänotypen des Mammakarzinoms ist das TNBC in den Mittelpunkt des Interesses gerückt. Das TNBC macht etwa $10-24 \%$ aller Fälle von Brustkrebs aus und tritt am häufigsten bei jüngeren Patientinnen und bei Patientinnen mit BRCA1-Mutation auf. Es besteht eine erhebliche Heterogenität der TNBCs sowohl auf der morphologischen als auch auf der molekularen Ebene, es gibt aber auch gemeinsame Eigenschaften wie ein geringer Differenzierungsgrad und eine erhöhte Proliferationsaktivität. Morphologisch kann sich das TNBC als invasiv-duktaler, metaplastischer, medullärer, apokriner oder anderer Phänotyp präsentieren. Auf molekularer Ebene ist das TNBC am häufigsten mit einem basalen Phänotyp assoziiert, seltenere molekulare Varianten des TNBC betreffen den Claudin-low und den molekular-apokrinen Typ. Der basale Phänotyp ist nicht selten mit einem Verlust von BRCA1 assoziiert.

traditional classification of breast cancer, but its prognostic and predictive relevance is rather limited. Tumors with identical type, grade and stage can have markedly different outcomes, and as a result, some patients may be overtreated or undertreated. For the success of targeted therapy and individualized medicine, a predictive rather than purely prognostic classification system would be required.

\section{KARGER \\ Fax +497614520714 \\ Information@Karger.de}

www.karger.com (c) 2011 S. Karger GmbH, Freiburg

$1661-3791 / 11 / 0064-0273 \$ 38.00 / 0$

Accessible online at:

www.karger.com/brc
Prof. Dr. Hans-Peter Sinn

Pathologisches Institut der Universität

Im Neuenheimer Feld 220, 69120 Heidelberg, Germany

Tel. +49 6221 56-931, Fax -4340

Peter.Sinn@med.uni-heidelberg.de 
In the last few years, the study of gene expression by microarray and related technologies (since 2000) has led to the definition of molecular phenotypes of breast cancer and has provided a more precise profile of the disease aiming at resolving the complexity of breast cancer and identifying related entities that share specific molecular alterations and are sensitive to specific treatments. The phenotypic classification of breast carcinoma has been based on unsupervised clustering of gene expression data [2] and basically distinguishes 5 main subtypes. The 2 most frequent subtypes are the estrogen receptor (ER)-positive luminal A and luminal B tumors, and the other 3 subtypes include ER-negative tumors with normal breast-like, human epidermal growth factor receptor 2 (HER2)-related, and basal-like groups. The luminal C subtype [2] could not be identified consistently. More recently, rare subtypes such as the molecular apocrine subtype [3] and the claudin-low subtype [4] of breast cancer were identified.

In contrast, the term triple-negative (TN) breast cancer is a pragmatic, clinical term, which correlates with the molecular classification but cannot be used to identify one or more molecular subtypes. For various reasons, TN breast cancers (TNBCs) have attracted the attention of both pathologists and oncologists. This is because they were reported to be more aggressive in general and more likely to recur and metastasize than other subtypes of breast cancer [5]. Secondly, they may differ from ER- and HER2-positive tumors in histogenesis, although their true origins and developmental mechanisms seem to be elusive [6]. Unlike common breast cancers, TNBC is resistant to our current HER2-targeted therapies such as trastuzumab and hormonal therapies such as tamoxifen and aromatase inhibitors. Thirdly, most TNBCs are basal-like breast cancers, which have distinct molecular and biological characteristics [7-10]. We will discuss TNBCs, and the term 'basal-like' will be used in our review as an important subgroup of TNBCs.

\section{Definition and Risk Factors of TNBC}

TNBCs are defined as breast cancers lacking both ERs and progesterone receptors (PgRs), and HER2 expression by immunohistochemistry. They account for approximately 10 $24 \%$ of all breast cancers [5, 11-15]. Because of their frequent expression of basal markers, such as basal cytokeratins, TNBCs are sometimes lumped together with basal-like breast cancers. However, it is important to bear in mind that these are overlapping but by no means identical groups of breast cancer.

$\mathrm{TN}$ and basal-like subtypes occur more commonly in the African-American population than in Caucasians and have a particular predominance in premenopausal women [16, 17], with younger age at diagnosis [5, 18-21]. Other risk factors include lifestyle factors such as an increased body mass index (obesity), sedentary lifestyle, and alcohol consumption
$[22,23]$. Dolle et al. [24] reported that the TNBC risk was 2.5 times increased in women who had used oral contraceptives for more than 1 year compared to women who had used oral contraceptives for less than 1 year or never.

\section{Histopathological Features}

TN and basal-like tumors have been characterized by several aggressive histopathological features, including high histological and nuclear tumor grade, large tumor size, elevated mitotic count, area of central fibrosis and necrosis, pushing margin of invasion, poor tubule formation, lymphocytic stromal response, and high nuclear-cytoplasmic ratio $[9,16$, 25-30]. The majority of TNBCs are invasive ductal carcinomas of no special type [31]; however, there are several other and mostly rare histological types that may frequently be TN. This includes atypical or typical medullary-like cancers [27, 32], apocrine carcinomas and pleomorphic lobular carcinomas [9], metaplastic carcinomas [27, 33], and adenoid cystic carcinomas [34]. The majority of metaplastic and medullary-like cancers also show a basal phenotype, which is rarely found in other special types of breast cancer $[32,35,36]$.

\section{Molecular Features in TN and Basal-Like Breast Cancers}

The triple-negative phenotype of breast cancer tumors significantly overlaps with the basal-like phenotype. The majority of, but not all, TNBCs (66-90\%) are associated with a basal phenotype and, conversely, a majority of, but not all, basallike tumors have a TN phenotype $[8,37,38]$. On the other hand, it was shown that a small but significant subgroup of basal-like breast cancers may express either hormone receptors or HER2 [38-40]. In fact, TNBCs represent a rather heterogeneous group at the molecular level. Gene expression studies have shown that TNBCs mostly belong to three distinct molecular classes: the basal-like group, the claudin-low group, and the molecular-apocrine group. The claudin-low tumors are characterized by stem cell features and features of epithelial-mesenchymal transition (EMT). They lack cell-cell junction proteins, including E-cadherin, and they frequently have an intense lymphocytic cell infiltrate [4]. The molecularapocrine subtype is also consistently seen in TN breast cancers, but also in HER2-overexpressing cancers [3, 41]. This subtype characteristically is positive for the androgen receptor and may be seen in patients with germ-line PTEN mutations (PTEN = phosphatase and tensin homolog) [42].

\section{Basal-Like Subtype}

The most frequent molecular subtype of TNBC is the basallike subtype. This basal phenotype accounts for approximately $16-18 \%$ of all invasive breast cancers [43, 44]. 
Although TN and basal-like breast cancers share many molecular and morphological features, TN and basal-like are not identical terms [13, 45-47]. The term TN is a term based on clinical assays for ER, PgR, and HER2, whereas the term basal-like is based on microarray gene expression assays [2, 48]. At the immunohistochemical level, basal-like breast cancers are characterized by the expression of proteins normally found in basal/myoepithelial cells of the normal breast, including high-molecular-weight (basal) cytokeratins (CK5/6, CK14, and CK17). Therefore, the term 'basal-like' stems from the similarity between the molecular profile of these tumors and that of basal/myoepithelial cells of the normal breast [48].

Tumors expressing basal cytokeratins are thought to originate from CK5-positive epithelial progenitor cells of the breast [49-51]. Although several definitions [27, 52] of basallike carcinomas have been proposed, there is no internationally accepted consensus on this. Most of the previous studies in the breast have defined the basal phenotype as the group of tumors expressing high-molecular-weight (basal) cytokeratins including CK5/6 [43, 53], CK14 [54], or both [55]. By contrast, other studies [56] showed that $76 \%$ of the tumors could be classified as basal-like on the basis of ER and HER2 negativity in conjunction with expression of CK5/6 and epidermal growth factor receptor (EGFR).

Basal-like breast cancers usually show high p53 protein expression [53, 57, 58], or a high rate of $p 53$ gene mutations [2, $31,59]$, and high expression of EGFR [27, 31, 56, 57, 60]. Also they may be associated with germ-line $B R C A 1$ mutations [45, 61] and often express genes associated with proliferation, such as those coding for cyclin E1 and proliferating cell nuclear antigen (PCNA) [2, 48, 62]. Association of basal-like breast cancer with elevated mRNA levels of p16 and cyclin E with lower levels of retinoblastoma $(\mathrm{Rb})$ and cyclin $\mathrm{D} 1$ compared to other tumor subtypes suggests that $R b$ inactivation is integrally linked to basal-like tumors [59]. In addition, the myoepithelial markers smooth muscle actin (SMA), p63 and CD10 are generally expressed [27].

The basal-like subtype has been associated with poor clinical outcome $[14,45]$. This probably reflects the subtype's association with a high proliferative capacity, a high histological grade, and the lack of systemic therapy, since basal-like tumors express a low level of ER and do not overexpress HER2 [44, 63]. In addition, Potemski et al. [64] have revealed that poor prognosis associated with the basal-like phenotype of breast cancer was determined not by CK5/6 or CK17 expression, but instead by ER absence and cyclin E expression.

\section{BRCAness in TN Cancers}

The two major contributors to hereditary breast cancer are the cancer susceptibility genes BRCA1 and BRCA2 [65]. $B R C A 1$ is a tumor suppressor gene expressed in the cells of breast and other tissue, where it helps repair damaged DNA and destroy cells when the DNA cannot be repaired. If $B R C A 1$ itself is damaged, the damaged DNA can allow the cell to duplicate without control, resulting in cancer [66]. This gene is responsible for most cases of hereditary breast and ovarian cancer. $B R C A 1$-associated cancers are typically high grade and TN, and share common pathologic features such as positive EGFR immunostaining [67-69]; also, Foulkes et al. [61] found that the majority of these BRCA1-associated cancers that are ER negative (81\%) are more likely to develop at a younger age (before age 45 ), compared to $62 \%$ of cancers in women diagnosed after age 65 . Furthermore, the proportion of $B R C A 1$-associated cancers that are of the basal phenotype has been estimated to be $88 \%$ and $57 \%$ by Foulkes et al. [61] and Lakhani et al. [67], respectively.

In addition, a number of studies have shown that BRCA1positive disease and TNBC/basal-like breast cancer share certain characteristics, including ER negativity, HER2 negativity, high nuclear grade, high Ki-67 labeling index, basal marker expression (CK5/6, 14, 17, EGFR), and tumor protein 53 (tp53) mutation [53, 61, 67, 70, 71]. Furthermore, Young et al. [72] have reported that young women with high-grade TNBC and with no family history of cancer are likely to carry a BRCA1 mutation. Microarray gene expression studies have also shown a similarity between sporadic basal-like tumors and those familial tumors harboring a BRCA1 mutation [45, 73]. In addition, Turner et al. [74] have suggested that tumors expressing more than one basal cytokeratin are more likely to have a dysfunctional BRCA1 pathway. Immunohistochemical profiling using tissue microarrays has identified that a group of tumors characterized by basal cytokeratin expression are also characterized by low expression of BRCA1 [58]. Indeed a basal phenotype is one of the hallmark features of 'BRCAness' (sporadic cancers that look like those from $B R C A 1$ or $B R C A 2$ mutation carriers) and might have important implications for management [71].

\section{Metastasis and Pattern of Recurrence}

TNBCs and basal-like cancers are more likely than others to metastasize to the brain [75, 76], and vice versa [77]. In a study of 55 patients with invasive breast cancer who developed brain metastases, the frequency of ER-negative, CK5/6-positive, and EGFR-positive tumors was higher than that observed in a comparison group of patients who did not have brain metastases [78]. Also, the incidence of central nervous system (CNS) metastases has been observed in AfricanAmericans and BRCA1 mutation carriers, and these two populations of patients have a relatively higher incidence of TN/basal-like tumors [79]. In particular, the risk of visceral recurrence within 5 years of diagnosis is significantly higher in TNBC patients, although the risk of bone recurrence in the same interval is significantly lower [80]. Also, tumors expressing basal markers are associated with more lung and brain metastases than comparable tumors not expressing basal markers [81]. 
Patients with TNBC exhibit a distinct pattern of recurrence, which is characterized by a rapidly rising rate in the first 2 years following diagnosis and a peak at 2-3 years, followed by a decline in recurrence risk over the next 5 years, and a very low risk of recurrence thereafter [5, 19]. The risk of distant recurrence and death due to breast cancer within 5 years of diagnosis is significantly higher in TNBC patients than in other patients with non-TN breast cancer [5].

\section{Prognosis}

Molecular subtypes of breast cancer are associated with different clinical outcomes [82]. Patients with basal phenotype [77] or TN tumors [5, 83] generally have a shorter disease-specific survival and overall survival than those with non-basal,
non-TN, or luminal A tumors. In addition, Liu et al. [84] have reported that, although the $\mathrm{TN}$ phenotype is related to poor prognosis in the whole breast cancer population, those positive for CK5/6 or CK17 had an even worse clinical outcome in the TN phenotype. Also, it was reported that TNBCs are associated with more advanced stage [85] and higher grade $[46,86]$, which are associated with worse prognosis in breast cancer. However, it is not clear if the poor prognosis of TNBCs and basal-like breast cancer is due to poor therapy options or inherent aggressiveness [82].

\section{Disclosure Statement}

None of these authors have personal financial interests or conflicts of interest to declare.

\section{References}

1 Tavassoli FA, Devilee P: Tumours of the breast and female genital organs. Pathology and Genetics. Lyon, IARC Press, 2003.

2 Sørlie T, Perou CM, Tibshirani R, Aas T, Geisler S, Johnsen H, Hastie T, Eisen MB, van de Rijn M, Jeffrey SS, Thorsen T, Quist H, Matese JC, Brown PO, Botstein D, Eystein Lonning P, Borresen-Dale AL: Gene expression patterns of breast carcinomas distinguish tumor subclasses with clinical implications. Proc Natl Acad Sci U S A 2001;98:10869-10874.

$\checkmark 3$ Weigelt B, Horlings HM, Kreike B, Hayes MM, Hauptmann M, Wessels LF, de Jong D, Van de Vijver MJ, Van't Veer LJ, Peterse JL: Refinement of breast cancer classification by molecular characterization of histological special types. J Pathol 2008;216:141-150.

4 Perou CM: Molecular stratification of triplenegative breast cancers. Oncologist 2010;15(suppl 5):39-48.

5 Dent R, Trudeau M, Pritchard KI, Hanna WM, Kahn HK, Sawka CA, Lickley LA, Rawlinson E, Sun P, Narod SA: Triple-negative breast cancer: Clinical features and patterns of recurrence. Clin Cancer Res 2007;13:4429-4434.

6 Bosch A, Eroles P, Zaragoza R, Vina JR, Lluch A: Triple-negative breast cancer: Molecular features, pathogenesis, treatment and current lines of research. Cancer Treat Rev 2010;36:206-215.

7 Rakha E, Elsheikh S, Aleskandarany M, Habashi H, Green A, Powe D, El-Sayed M, Benhasouna A, Brunet J, Akslen L, Evans A, Blamey R, ReisFilho J, Foulkes W, Ellis I: Triple-negative breast cancer: Distinguishing between basal and nonbasal subtypes. Clin Cancer Res 2009;15:2302-2310.

-8 Bertucci F, Finetti P, Cervera N, Esterni B, Hermitte F, Viens P, Birnbaum D: How basa are triple-negative breast cancers? Int $\mathrm{J}$ Cancer 2008;123:236-240.

$\checkmark$ Kreike B, van Kouwenhove M, Horlings H, Weigelt B, Peterse H, Bartelink H, van de Vijver MJ: Gene expression profiling and histopathological characterization of triple-negative/basal-like breast carcinomas. Breast Cancer Res 2007;9:R65.
10 Bidard FC, Conforti R, Boulet T, Michiels S, Delaloge S, Andre F: Does triple-negative phenotype accurately identify basal-like tumour? An immunohistochemical analysis based on 143 'triplenegative' breast cancers. Ann Oncol 2007;18:12851286.

11 Haffty BG, Yang Q, Reiss M, Kearney T, Higgins SA, Weidhaas J, Harris L, Hait W, Toppmeyer $\mathrm{D}$ : Locoregional relapse and distant metastasis in conservatively managed triple negative early-stage breast cancer. J Clin Oncol 2006;24:5652-5657.

12 Carey L, Dees E, Sawyer L, Gatti L, Moore D, Collichio F, Ollila D, Sartor C, Graham M, Perou C: The triple negative paradox: Primary tumor chemosensitivity of breast cancer subtypes. Clin Cancer Res 2007;13:2329-2334.

13 Rakha EA, El-Sayed ME, Green AR, Lee AH, Robertson JF, Ellis IO: Prognostic markers in triple-negative breast cancer. Cancer 2007;109:25-32.

14 Reis-Filho JS, Tutt AN: Triple negative tumours: A critical review. Histopathology 2008;52:108-118.

15 Schneider BP, Winer EP, Foulkes WD, Garber J, Perou CM, Richardson A, Sledge GW, Carey LA: Triple-negative breast cancer: Risk factors to potential targets. Clin Cancer Res 2008;14:8010-8018.

16 Bauer K, Brown M, Cress R, Parise C, Caggiano V: Descriptive analysis of estrogen receptor (ER)negative, progesterone receptor (PR)-negative, and HER2-negative invasive breast cancer, the so-called triple-negative phenotype: A populationbased study from the California Cancer Registry. Cancer 2007;109:1721-1728.

17 Morris GJ, Naidu S, Topham AK, Guiles F, Xu Y, McCue P, Schwartz GF, Park PK, Rosenberg AL, Brill K, Mitchell EP: Differences in breast carcinoma characteristics in newly diagnosed AfricanAmerican and Caucasian patients: A single-institution compilation compared with the National Cancer Institute's Surveillance, Epidemiology, and End Results Database. Cancer 2007;110:876-884.

18 Ihemelandu CU, Leffall LD Jr, Dewitty RL, Naab TJ, Mezghebe HM, Makambi KH, AdamsCampbell L, Frederick WA: Molecular breast cancer subtypes in premenopausal and postmenopausal African-American women: Age-specific prevalence and survival. J Surg Res 2007;143:109_ 118 .
19 Tischkowitz M, Brunet JS, Begin LR, Huntsman DG, Cheang MC, Akslen LA, Nielsen TO, Foulkes WD: Use of immunohistochemical markers can refine prognosis in triple negative breast cancer. BMC Cancer 2007;7:134.

20 Bowen RL, Duffy SW, Ryan DA, Hart IR, Jones JL: Early onset of breast cancer in a group of British black women. Br J Cancer 2008;98:277-281.

21 Lund MJ, Trivers KF, Porter PL, Coates RJ, Leyland-Jones B, Brawley OW, Flagg EW, O'Regan RM, Gabram SG, Eley JW: Race and triple negative threats to breast cancer survival: A population-based study in Atlanta, GA. Breast Cancer Res Treat 2009;113:357-370.

22 Trivers KF, Lund MJ, Porter PL, Liff JM, Flagg EW, Coates RJ, Eley JW: The epidemiology of triple-negative breast cancer, including race. Cancer Causes Control 2009;20:1071-1082.

23 Shinde SS, Forman MR, Kuerer HM, Yan K, Peintinger F, Hunt KK, Hortobagyi GN, Pusztai L, Symmans WF: Higher parity and shorter breastfeeding duration: Association with triple-negative phenotype of breast cancer. Cancer 2010;116:4933-4943.

24 Dolle JM, Daling JR, White E, Brinton LA, Doody DR, Porter PL, Malone KE: Risk factors for triple-negative breast cancer in women under the age of 45 years. Cancer Epidemiol Biomarkers Prev 2009;18:1157-1166.

25 Tot T: The cytokeratin profile of medullary carcinoma of the breast. Histopathology 2000;37:175181.

26 Fulford L, Easton D, Reis-Filho J, Sofronis A, Gillett C, Lakhani S, Hanby A: Specific morphological features predictive for the basal phenotype in grade 3 invasive ductal carcinoma of breast. Histopathology 2006;49:22-34.

27 Livasy CA, Karaca G, Nanda R, Tretiakova MS, Olopade OI, Moore DT, Perou CM: Phenotypic evaluation of the basal-like subtype of invasive breast carcinoma. Mod Pathol 2006;19:264-271.

28 Millikan RC, Newman B, Tse CK, Moorman PG, Conway K, Dressler LG, Smith LV, Labbok MH, Geradts J, Bensen JT, Jackson S, Nyante S, Livasy C, Carey L, Earp HS, Perou CM: Epidemiology of basal-like breast cancer. Breast Cancer Res Treat 2008;109:123-139. 
29 Sasa M, Bando Y, Takahashi M, Hirose T, Nagao T: Screening for basal marker expression is necessary for decision of therapeutic strategy for triple-negative breast cancer. J Surg Oncol 2008;97: 30-34.

-30 Kaplan HG, Malmgren JA, Atwood M: T1N0 triple negative breast cancer: Risk of recurrence and adjuvant chemotherapy. Breast J 2009;15:454460.

31 Carey LA, Perou CM, Livasy CA, Dressler LG, Cowan D, Conway K, Karaca G, Troester MA, Tse CK, Edmiston S, Deming SL, Geradts J, Cheang MC, Nielsen TO, Moorman PG, Earp HS, Millikan RC: Race, breast cancer subtypes, and survival in the Carolina Breast Cancer Study. JAMA 2006;295:2492-2502.

-32 Jacquemier J, Padovani L, Rabayrol L, Lakhani SR, Penault-Llorca F, Denoux Y, Fiche M, Figueiro P, Maisongrosse V, Ledoussal V, Martinez Penuela J, Udvarhely N, El Makdissi G, Ginestier C, Geneix J, Charafe-Jauffret E, Xerri L, Eisinger F, Birnbaum D, Sobol H: Typical medullary breast carcinomas have a basal/myoepithelial phenotype. J Pathol 2005;207:260-268.

33 Reis-Filho JS, Milanezi F, Steele D, Savage K, Simpson PT, Nesland JM, Pereira EM, Lakhani SR, Schmitt FC: Metaplastic breast carcinomas are basal-like tumours. Histopathology 2006;49:10-21.

>34 Cleator S, Heller W, Coombes R: Triple-negative breast cancer: Therapeutic options. Lancet Oncol 2007;8:235-244.

35 Bertucci F, Finetti P, Cervera N, Charafe-Jauffret E, Mamessier E, Adelaide J, Debono S, Houvenaeghel G, Maraninchi D, Viens P, Charpin C, Jacquemier J, Birnbaum D: Gene expression profiling shows medullary breast cancer is a subgroup of basal breast cancers. Cancer Res 2006;66:46364644.

-36 Rodriguez-Pinilla SM, Rodriguez-Gil Y, MorenoBueno G, Sarrio D, Martin-Guijarro Mdel C, Hernandez L, Palacios J: Sporadic invasive breast carcinomas with medullary features display a basal-like phenotype: An immunohistochemical and gene amplification study. Am J Surg Pathol 2007;31:501-508.

37 Rakha E, Tan D, Foulkes W, Ellis I, Tutt A, Nielsen T, Reis-Filho J: Are triple-negative tumours and basal-like breast cancer synonymous? Breast Cancer Res 2007;9:404; author reply 405.

38 Rakha EA, Ellis IO, Reis-Filho JS: Immunohistochemical heterogeneity of breast carcinomas negative for estrogen receptors, progesterone receptors and HER2/neu (basal-like breast carcinomas). Mod Pathol 2008;21:1060-1061; author reply 10611062.

\$3 Calza S, Hall P, Auer G, Bjohle J, Klaar S, Kronenwett U, Liu ET, Miller L, Ploner A Smeds J, Bergh J, Pawitan Y: Intrinsic molecular signature of breast cancer in a populationbased cohort of 412 patients. Breast Cancer Res 2006;8:R34.

40 Jumppanen M, Gruvberger-Saal S, Kauraniemi P, Tanner M, Bendahl PO, Lundin M, Krogh M, Kataja P, Borg A, Ferno M, Isola J: Basal-like phenotype is not associated with patient survival in estrogen-receptor-negative breast cancers. Breast Cancer Res 2007;9:R16.

41 Lopez-Garcia MA, Geyer FC, Lacroix-Triki M, Marchio C, Reis-Filho JS: Breast cancer precursors revisited: Molecular features and progression pathways. Histopathology 2010;57:171-192.
42 Banneau G, Guedj M, MacGrogan G, de Mascarel I, Velasco V, Schiappa R, Bonadona V, David A, Dugast C, Gilbert-Dussardier B, Ingster O, Vabres P, Caux F, de Reynies A, Iggo R, Sevenet N, Bonnet F, Longy M: Molecular apocrine differentiation is a common feature of breast cancer in patients with germline PTEN mutations. Breast Cancer Res 2010;12:R63.

43 van de Rijn M, Perou CM, Tibshirani R, Haas P, Kallioniemi O, Kononen J, Torhorst J, Sauter G, Zuber M, Koechli OR, Mross F, Dieterich H, Seitz R, Ross D, Botstein D, Brown P: Expression of cytokeratins 17 and 5 identifies a group of breast carcinomas with poor clinical outcome. Am J Pathol 2002;161:1991-1996.

44 Abd El-Rehim DM, Pinder SE, Paish CE, Bell J, Blamey RW, Robertson JF, Nicholson RI, Ellis IO: Expression of luminal and basal cytokeratins in human breast carcinoma. J Pathol 2004;203:661-671.

45 Sorlie T, Tibshirani R, Parker J, Hastie T, Marron JS, Nobel A, Deng S, Johnsen H, Pesich R, Geisler S, Demeter J, Perou CM, Lonning PE, Brown PO, Borresen-Dale AL, Botstein D: Repeated observation of breast tumor subtypes in independent gene expression data sets. Proc Natl Acad Sci U S A 2003;100:8418-8423.

46 Tan D, Marchió C, Jones R, Savage K, Smith I, Dowsett M, Reis-Filho J: Triple negative breast cancer: Molecular profiling and prognostic impact in adjuvant anthracycline-treated patients. Breast Cancer Res Treat 2008;111:27-44.

47 Kuroda N, Ohara M, Inoue K, Mizuno K, Fujishima N, Hamaguchi N, Lee GH: The majority of triple-negative breast cancer may correspond to basal-like carcinoma, but triple-negative breast cancer is not identical to basal-like carcinoma. Med Mol Morphol 2009;42:128-131.

48 Perou CM, Sorlie T, Eisen MB, van de Rijn M, Jeffrey SS, Rees CA, Pollack JR, Ross DT, Johnsen H, Akslen LA, Fluge O, Pergamenschikov A, Williams C, Zhu SX, Lonning PE, Borresen-Dale AL, Brown PO, Botstein D: Molecular portraits of human breast tumours. Nature 2000;406:747-752.

49 Böcker W, Moll R, Poremba C, Holland R, Van Diest $\mathrm{P}$, Dervan $\mathrm{P}$, Bürger $\mathrm{H}$, Wai D, Ina Diallo $\mathrm{R}$, Brandt $\mathrm{B}$, Herbst $\mathrm{H}$, Schmidt $\mathrm{A}$, Lerch M, Buchwallow I: Common adult stem cells in the human breast give rise to glandular and myoepithelial cell lineages: A new cell biological concept. Lab Invest 2002;82:737-746.

50 Clayton H, Titley I, Vivanco M: Growth and differentiation of progenitor/stem cells derived from the human mammary gland. Exp Cell Res 2004;297:444-460.

51 Tsuda H, Morita D, Kimura M, Shinto E, Ohtsuka Y, Matsubara O, Inazawa J, Tamaki K, Mochizuki H, Tamai S, Hiraide H: Correlation of Kit and EGFR overexpression with invasive ductal breast carcinoma of the solid-tubular subtype, nuclear grade 3 , and mesenchymal or myoepithelial differentiation. Cancer Sci 2005;96:48-53.

52 Matos I, Dufloth R, Alvarenga M, Zeferino LC, Schmitt F: p63, cytokeratin 5, and P-cadherin: Three molecular markers to distinguish basal phenotype in breast carcinomas. Virchows Arch 2005;447:688-694.
3 Foulkes W, Brunet J, Stefansson I, Straume O, Chappuis P, Bégin L, Hamel N, Goffin J, Wong N, Trudel M, Kapusta L, Porter P, Akslen L: The prognostic implication of the basal-like (cyclin E high/p27 low/p53+/glomeruloid-microvascular-proliferation+) phenotype of BRCA1-related breast cancer. Cancer Res 2004;64:830-835.

54 Jones C, Ford E, Gillett C, Ryder K, Merrett S, Reis-Filho JS, Fulford LG, Hanby A, Lakhani SR: Molecular cytogenetic identification of subgroups of grade III invasive ductal breast carcinomas with different clinical outcomes. Clin Cancer Res 2004;10:5988-5997.

55 Bankfalvi A, Ludwig A, De-Hesselle B, Buerger H, Buchwalow IB, Böcker W: Different proliferative activity of the glandular and myoepithelial lineages in benign proliferative and early malignant breast diseases. Mod Pathol 2004;17:1051-1061.

56 Nielsen TO, Hsu FD, Jensen K, Cheang M, Karaca G, Hu Z, Hernandez-Boussard T, Livasy C, Cowan D, Dressler L, Akslen LA, Ragaz J, Gown AM, Gilks CB, van de Rijn M, Perou CM: Immunohistochemical and clinical characterization of the basal-like subtype of invasive breast carcinoma. Clin Cancer Res 2004;10:5367-5374.

57 Korsching E, Packeisen J, Agelopoulos K, Eisenacher M, Voss R, Isola J, van Diest $\mathrm{P}$, Brandt B, Boecker W, Buerger H: Cytogenetic alterations and cytokeratin expression patterns in breast cancer: Integrating a new model of breast differentiation into cytogenetic pathways of breast carcinogenesis. Lab Invest 2002;82:1525-1533.

58 Abd El-Rehim DM, Ball G, Pinder SE, Rakha E, Paish C, Robertson JF, Macmillan D, Blamey RW, Ellis IO: High-throughput protein expression analysis using tissue microarray technology of a large well-characterised series identifies biologically distinct classes of breast cancer confirming recent cDNA expression analyses. Int $\mathrm{J}$ Cancer 2005; $116: 340-350$

59 Troester MA, Herschkowitz JI, Oh DS, He X, Hoadley KA, Barbier CS, Perou CM: Gene expression patterns associated with p53 status in breast cancer. BMC Cancer 2006;6:276.

60 Dogu GG, Ozkan M, Ozturk F, Dikilitas M, Er O, Ozturk A: Triple-negative breast cancer: Immunohistochemical correlation with basaloid markers and prognostic value of survivin. Med Oncol 2010;27:34-39.

61 Foulkes WD, Stefansson IM, Chappuis PO, Begin LR, Goffin JR, Wong N, Trudel M, Akslen LA: Germline BRCA1 mutations and a basal epithelial phenotype in breast cancer. J Natl Cancer Inst 2003;95:1482-1485.

62 Sotiriou C, Neo SY, McShane LM, Korn EL, Long PM, Jazaeri A, Martiat P, Fox SB, Harris AL, Liu ET: Breast cancer classification and prognosis based on gene expression profiles from a population-based study. Proc Natl Acad Sci U S A 2003;100:10393-10398.

63 Gusterson B, Ross D, Heath V, Stein T: Basal cytokeratins and their relationship to the cellular origin and functional classification of breast cancer. Breast Cancer Res 2005;7:143-148.

64 Potemski P, Kusinska R, Watala C, Pluciennik E, Bednarek A, Kordek R: Prognostic relevance of basal cytokeratin expression in operable breast cancer. Oncology 2005;69:478-485.

- 65 Narod SA, Foulkes WD: BRCA1 and BRCA2: 1994 and beyond. Nat Rev Cancer 2004;4:665-676. 
66 Friedenson B: The BRCA1/2 pathway prevents hematologic cancers in addition to breast and ovarian cancers. BMC Cancer 2007;7:152.

67 Lakhani SR, Reis-Filho JS, Fulford L, PenaultLlorca F, van der Vijver M, Parry S, Bishop T, Benitez J, Rivas C, Bignon YJ, Chang-Claude J, Hamann U, Cornelisse CJ, Devilee P, Beckmann MW, Nestle-Kramling C, Daly PA, Haites N, Varley J, Lalloo F, Evans G, Maugard C, MeijersHeijboer H, Klijn JG, Olah E, Gusterson BA, Pilotti S, Radice P, Scherneck S, Sobol H, Jacquemier J, Wagner T, Peto J, Stratton MR, McGuffog L, Easton DF: Prediction of BRCA1 status in patients with breast cancer using estrogen receptor and basal phenotype. Clin Cancer Res 2005; 11:5175-5180.

68 van der Groep P, Bouter A, van der Zanden R, Siccama I, Menko FH, Gille JJ, van Kalken C, van der Wall E, Verheijen RH, van Diest PJ: Distinction between hereditary and sporadic breast cancer on the basis of clinicopathological data. J Clin Pathol 2006;59:611-617.

69 Atchley DP, Albarracin CT, Lopez A, Valero V, Amos CI, Gonzalez-Angulo AM, Hortobagyi GN Arun BK: Clinical and pathologic characteristics of patients with BRCA-positive and BRCA-negative breast cancer. J Clin Oncol 2008;26:4282-4288.

70 Crook T, Brooks LA, Crossland S, Osin P, Barker KT, Waller J, Philp E, Smith PD, Yulug I, Peto J, Parker G, Allday MJ, Crompton MR, Gusterson BA: p53 mutation with frequent novel codons but not a mutator phenotype in BRCA1- and BRCA2-associated breast tumours. Oncogene 1998;17:1681-1689.

71 Turner N, Tutt A, Ashworth A: Hallmarks of 'BRCAness' in sporadic cancers. Nat Rev Cancer 2004;4:814-819.

-72 Young SR, Pilarski RT, Donenberg T, Shapiro C, Hammond LS, Miller J, Brooks KA, Cohen S, Tenenholz B, Desai D, Zandvakili I, Royer R, Li $S$, Narod SA: The prevalence of BRCA1 mutations among young women with triple-negative breast cancer. BMC Cancer 2009;9:86.
73 Hedenfalk I, Duggan D, Chen Y, Radmacher M, Bittner M, Simon R, Meltzer P, Gusterson B, Esteller M, Kallioniemi OP, Wilfond B, Borg A, Trent J, Raffeld M, Yakhini Z, Ben-Dor A, Dougherty E, Kononen J, Bubendorf L, Fehrle W, Pittaluga S, Gruvberger S, Loman N, Johannsson $\mathrm{O}$, Olsson H, Sauter G: Gene-expression profiles in hereditary breast cancer. N Engl J Med 2001;344:539-548.

74 Turner NC, Reis-Filho JS, Russell AM, Springall RJ, Ryder K, Steele D, Savage K, Gillett CE, Schmitt FC, Ashworth A, Tutt AN: BRCA1 dysfunction in sporadic basal-like breast cancer. Oncogene 2007;26:2126-2132.

75 Harrell JC, Prat A, Parker JS, Fan C, He X, Carey L, Anders C, Ewend M, Perou CM: Genomic analysis identifies unique signatures predictive of brain, lung, and liver relapse. Breast Cancer Res Treat 2011, in press.

76 Heitz F, Harter P, Lueck HJ, Fissler-Eckhoff A, Lorenz-Salehi F, Scheil-Bertram S, Traut A, du Bois A: Triple-negative and HER2-overexpressing breast cancers exhibit an elevated risk and an earlier occurrence of cerebral metastases. Eur J Cancer 2009;45:2792-2798.

77 Fulford L, Reis-Filho J, Ryder K, Jones C, Gillett C, Hanby A, Easton D, Lakhani S: Basallike grade III invasive ductal carcinoma of the breast: Patterns of metastasis and long-term survival. Breast Cancer Res 2007;9:R4.

78 Hicks DG, Short SM, Prescott NL, Tarr SM, Coleman KA, Yoder BJ, Crowe JP, Choueiri TK, Dawson AE, Budd GT, Tubbs RR, Casey G, Weil RJ: Breast cancers with brain metastases are more likely to be estrogen receptor negative, express the basal cytokeratin CK5/6, and overexpress HER2 or EGFR. Am J Surg Pathol 2006;30:10971104.

79 Barnholtz-Sloan JS, Sloan AE, Davis FG, Vigneau FD, Lai P, Sawaya RE: Incidence proportions of brain metastases in patients diagnosed (1973 to 2001) in the Metropolitan Detroit Cancer Surveillance System. J Clin Oncol 2004;22:28652872.
80 Dent R, Hanna WM, Trudeau M, Rawlinson E, Sun P, Narod SA: Pattern of metastatic spread in triple-negative breast cancer. Breast Cancer Res Treat 2009;115:423-428.

81 Tsuda H, Takarabe T, Hasegawa F, Fukutomi T, Hirohashi S: Large, central acellular zones indicating myoepithelial tumor differentiation in highgrade invasive ductal carcinomas as markers of predisposition to lung and brain metastases. Am J Surg Pathol 2000;24:197-202.

82 Parker JS, Mullins M, Cheang MC, Leung S, Voduc D, Vickery T, Davies S, Fauron C, He X, Hu Z, Quackenbush JF, Stijleman IJ, Palazzo J, Marron JS, Nobel AB, Mardis E, Nielsen TO, Ellis MJ, Perou CM, Bernard PS: Supervised risk predictor of breast cancer based on intrinsic subtypes. J Clin Oncol 2009;27:1160-1167.

83 Harris L, Broadwater G, Lin N, Miron A, Schnitt S, Cowan D, Lara J, Bleiweiss I, Berry D, Ellis M, Hayes D, Winer E, Dressler L: Molecular subtypes of breast cancer in relation to paclitaxel response and outcomes in women with metastatic disease: Results from CALGB 9342. Breast Cancer Res 2006;8:R66.

84 Liu ZB, Wu J, Ping B, Feng LQ, Di GH, Lu JS, Shen KW, Shen ZZ, Shaol ZM: Basal cytokeratin expression in relation to immunohistochemical and clinical characterization in breast cancer patients with triple negative phenotype. Tumori 2009;95:5362.

85 Lund MJ, Butler EN, Bumpers HL, Okoli J, Rizzo M, Hatchett N, Green VL, Brawley OW, Oprea-Ilies GM, Gabram SG: High prevalence of triple-negative tumors in an urban cancer center. Cancer 2008;113:608-615.

86 Rakha EA, El-Rehim DA, Paish C, Green AR, Lee AH, Robertson JF, Blamey RW, Macmillan D, Ellis IO: Basal phenotype identifies a poor prognostic subgroup of breast cancer of clinical importance. Eur J Cancer 2006;42:3149-3156. 